\title{
Chicxulub central crater structure: Initial results from physical property measurements and combined velocity and gravity modeling
}

\author{
P. M. VERMEESCH and J. V. MORGAN* \\ Department of Earth Science and Engineering, Imperial College London, SW7 2AZ, UK \\ *Corresponding author. E-mail: j.v.morgan@imperial.ac.uk
}

(Received 15 July 2003; revision accepted 22 April 2004)

\begin{abstract}
The Chicxulub crater in Mexico is a nearly pristine example of a large impact crater. Its slow burial has left the central impact basin intact, within which there is an apparently uneroded topographic peak ring. Its burial, however, means that we must rely on drill holes and geophysical data to interpret the crater form. Interpretations of crater structures using geophysical data are often guided by numerical modeling and observations at other large terrestrial craters. However, such endeavors are hindered by uncertainties in current numerical models and the lack of any obvious progressive change in structure with increasing crater size. For this reason, proposed structural models across Chicxulub remain divergent, particularly within the central crater region, where the deepest well is only $\sim 1.6 \mathrm{~km}$ deep. The shape and precise location of the stratigraphic uplift are disputed. The spatial extent and distribution of the allogenic impact breccias and melt rocks remain unknown, as do the lithological nature of the peak ring and the mechanism for its formation.

The objective of our research is to provide a well-constrained 3D structural and lithological model across the central region of the Chicxulub crater that is consistent with combined geophysical data sets and drill core samples. With this in mind, we present initial physical property measurements made on 18 core samples from the Yaxcopoil-1 (Yax-1) drill hole between 400 and $1500 \mathrm{~m}$ deep and present a new density model that is in agreement with both the $3 \mathrm{D}$ velocity and gravity data. Future collation of petrophysical and geochemical data from Yax-1 core, as well as further seismic surveys and drilling, will allow us to calibrate our geophysical models - assigning a suite of physical properties to each lithology. An accurate 3D model of Chicxulub is critical to our understanding of large craters and to the constraining of the environmental effects of this impact.
\end{abstract}

\section{INTRODUCTION}

Extraterrestrial impact craters reveal that complex crater morphology changes with increasing crater size, from impact basins with a central peak to those with a peak ring and, finally, to multi-ring basins that may or may not contain a topographic peak ring (e.g., Melosh 1989). To fully understand these morphological changes, we need to map the subsurface crater structure, and only terrestrial craters can provide these data. Unfortunately, only a relatively small sample of the terrestrial crater population has been identified (e.g., Grieve 1998). Many of these craters are eroded, buried, or tectonically deformed, and only three (Vredefort, Sudbury, and Chicxulub) are greater than $150 \mathrm{~km}$ in diameter (e.g., Grieve and Therriault 2000). The Chicxulub crater is the most pristine of the larger-sized craters. This is apparent by the presence of a topographic peak ring that remains several hundred meters high within the impact basin (Morgan and Warner 1999; Grieve and Therriault 2004). Ejecta deposits have been observed within all wells drilled around the crater (e.g., Urrutia-Fucugauchi et al. 1996), indicating that the postimpact surface was not subject to extensive erosion, with only the lack of a clear crater rim (Hildebrand et al. 1998) indicating a modification of the original crater surface. The crater has been preserved because it lies on a relatively stable platform shelf and has been slowly buried by post-impact sediments. The latter is indicated both by the stratigraphic age of sediments in the impact basin (Smit et al. 2004) and the offshore seismic stratigraphy (Bell et al. 2004). As a wellpreserved large crater, Chicxulub offers us a unique opportunity to understand the formation of large craters.

However, the burial of the Chicxulub crater means that we must rely on geophysical surveys and drilling to understand this crater. With this in mind, there have been 
numerous geophysical investigations (Camargo-Zanoguera and Suárez-Reynoso 1994; Pilkington et al. 1994; Espindola et al. 1995; Sharpton et al. 1996; Morgan et al. 1997, 2000; Campos-Enriquez et al. 1998; Christeson et al. 2001; Ebbing et al. 2001), a concerted drilling program by the Universidad
Nacional Autónoma de México (UNAM), and most recently, Yax-1 (Fig. 1) has been drilled as part of the International Scientific Drilling Project (ICDP). With a lack of drill holes below a depth of $1.63 \mathrm{~km}$ (Fig. 1), the central crater structure remains the least well-constrained region of the Chicxulub
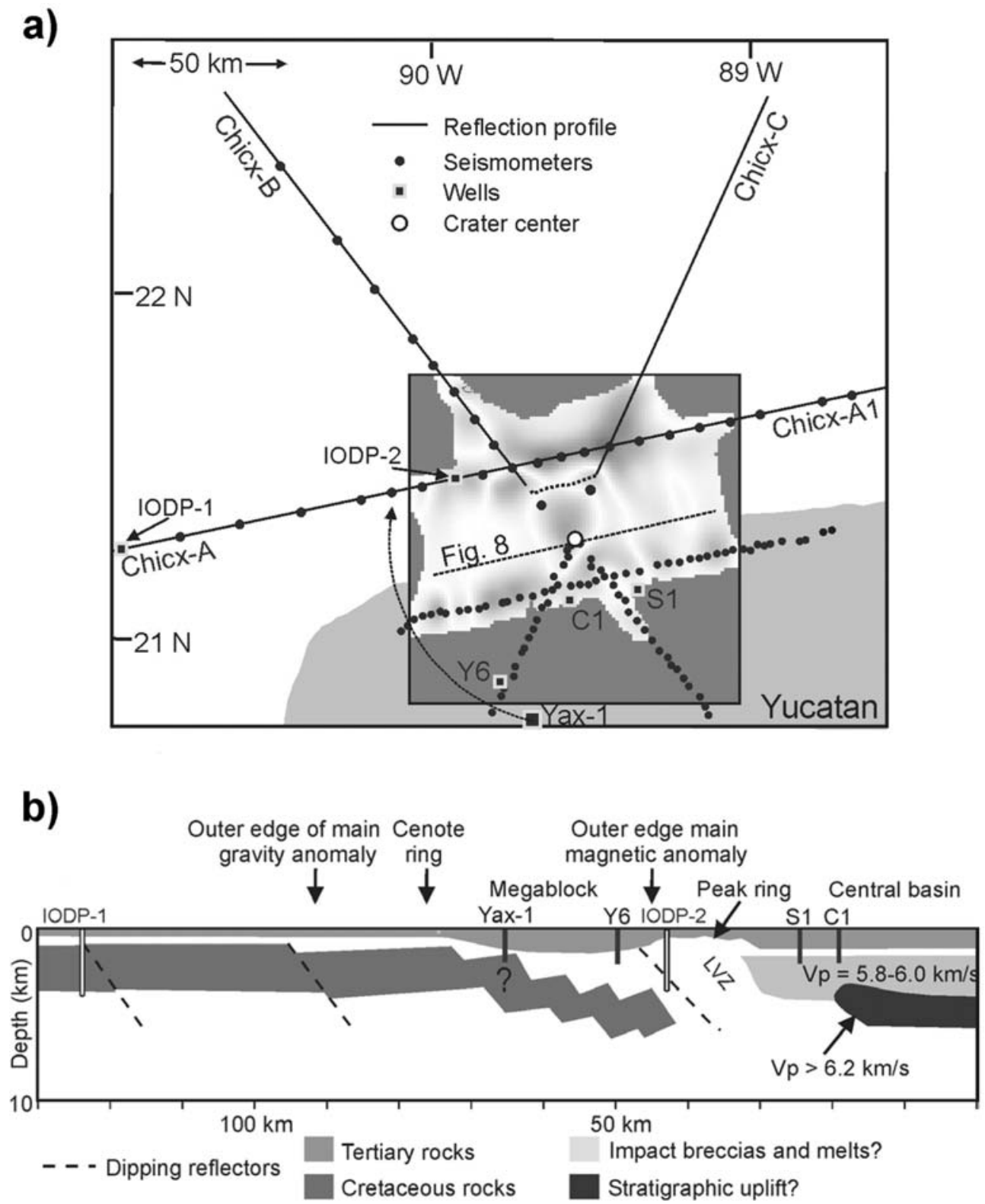

Fig. 1. a) Location map showing offshore seismic reflection lines, land, and ocean-bottom seismometer sites and well locations. Yax-1 is located $\sim 62 \mathrm{~km}$ to the south of the crater center. The circular dashed line shows the projection of Yax-1 onto seismic reflection line Chicx-A. The straight dashed line shows the location of the gravity profile in Fig. 9. The square box shows the location of the 3D velocity tomogram (Morgan et al. 2002a) within which the central white area indicates the zone that is well-constrained across the stratigraphic uplift. IODP-1 and -2 show the proposed location of two drill holes from proposal IODP-548 submitted to the Integrated Ocean Drilling Program (IODP); b) a cartoon of the Chicxulub crater, redrawn from Morgan et al. (2002a). The mapping of the Tertiary and Cretaceous rocks and of the peak ring is from offshore seismic reflection data (e.g., Morgan and Warner 1999). Structures within the central crater region are based on velocity data obtained from 3D tomographic seismic refraction data (Morgan et al. 2000, 2002a). $V_{P}$ is P-wave velocity; LVZ is low-velocity-zone. Drill holes are plotted at the appropriate radial distance from the crater center (see [a]). When projected onto the offshore seismic reflection data, Yax-1 is located in the megablock zone (see [a] for projection). Yax-1 has drilled into Cretaceous strata (annotated with a question mark) that have been interpreted as either slumped or ejected block(s) of target rock (Kenkmann et al. 2004). IODP-1 and -2 are the proposed locations of two IODP drill holes. 
crater. Interpretations of the Chicxulub structure are guided by numerical modeling and observations at other terrestrial craters. With this in mind, we present a brief summary of the numerical modeling of the Chicxulub crater and review the geometry of some terrestrial complex craters. We follow this with an overview of geophysical-based models of Chicxulub and summarize the current uncertainties in such models.

The objective of our long-term project is to obtain a wellconstrained 3D structural and lithological model of the central crater using combined geophysical data and results from drilling. In this paper, we present our initial results: a first suite of physical property measurements from the Yax-1 core and a new gravity model that is consistent with $3 \mathrm{D}$ velocity data.

\section{NUMERICAL MODELS}

Models for the formation of large complex craters all show an upward movement within the center of the crater during collapse (e.g., Grieve et al. 1981). When excavation has ceased, the uplifted rim collapses inward and downward to form a terrace zone, and the uplifted central zone collapses downward and outward to form a peak ring (Fig. 2a). The gradual decrease in peak ring to crater rim ratio with increasing crater size on Venus is a strong indicator that central peaks (stratigrapically uplifted material) collapse to form topographic peak rings (Alexopoulos and McKinnon 1994). To model crater formation, not only must we be able to reproduce the observed crater morphology but also the kinematics of crater collapse. Unfortunately, for most terrestrial examples, kinematic data tend to be onedimensional and biased toward sub-vertical motions. The latter occurs because sub-vertical kinematic displacements (faults) tend to be much easier to recognize than subhorizontal ones in both geological mapping and seismic reflection data. However, the exposure of the Rochechouart crater (26 km in diameter), in Champagnac quarry, provides a a)

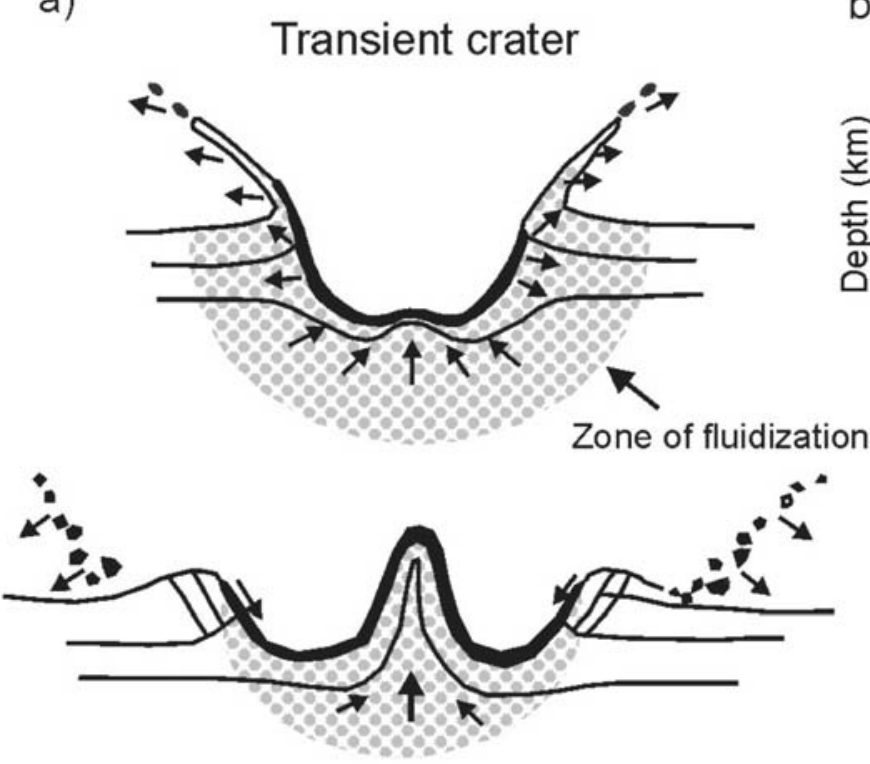

Final crater

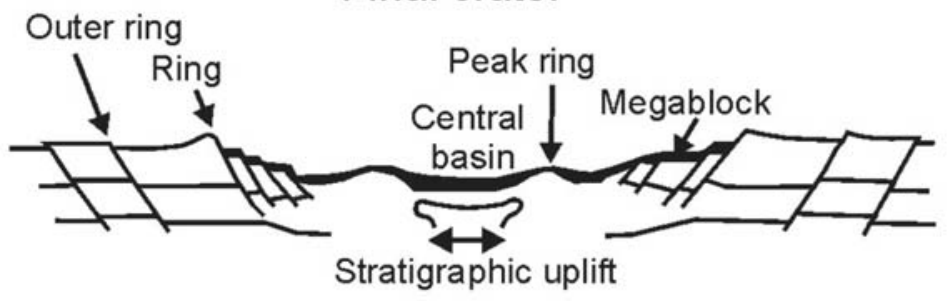

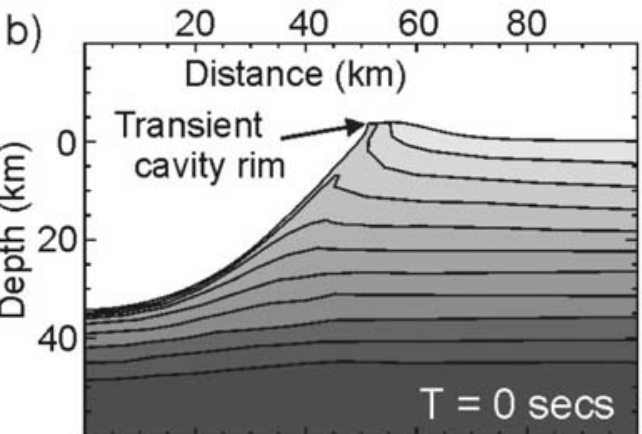
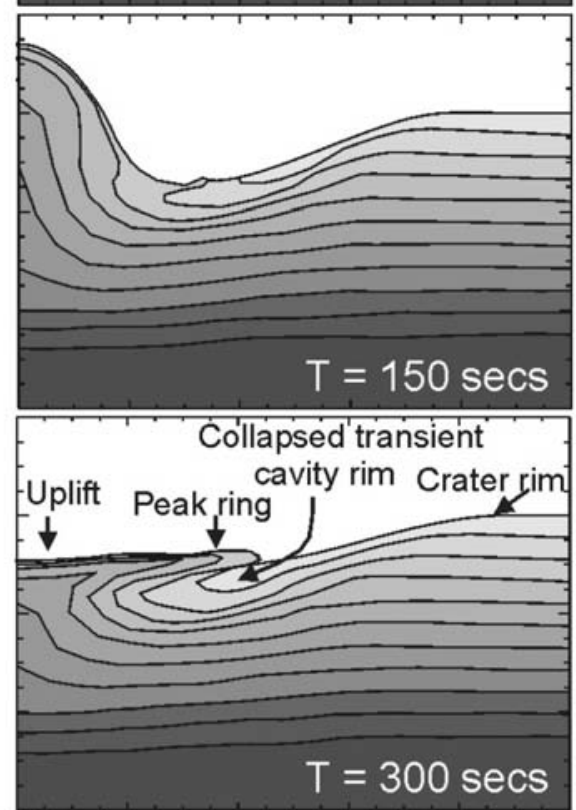

Fig. 2. a) Generic model for the formation of a large impact crater, redrawn from Melosh (1989). Material that is initially uplifted to form the rim of the transient cavity collapses inward and downward to form a megablock or terrace zone. Material that lies within the crater center initially moves upward and then downward and outward so that the final crater has stratigraphically uplifted material within the central crater and a peak ring. The shading represents material that behaves hydro-dynamically during crater collapse; b) numerical model of crater collapse from Collins et al. (2002). In this model, the peak ring is formed as stratigrapically uplifted material overrides the megablock zone. Note that, in the final crater, material that started within the transient crater rim ends up beneath the peak ring. 
unique insight into the deep basement of the crater (Kenkmann et al. 2000; Fig. 3a). These data provide vital clues to the kinematics of crater formation. Near the crater rim, the collapse is sub-vertical, while within the impact basin, the movement is inward and sub-horizontal. The stratigraphic uplift appears to collapse upward and outward and ride above the inward-collapsing material.

Observations at Rochechouart are in broad agreement with the predictions of numerical models of the Chicxulub crater (e.g., O'Keefe and Ahrens 1999; Pierazzo and Melosh 1999; Morgan et al. 2000; Ivanov and Artemieva 2002), even though these studies use different modeling code and weakening mechanisms (thermal softening versus acoustic fluidization). However, the precise kinematics and dynamics of collapse varies between models, and a range of parameterizations can produce similar final crater profiles
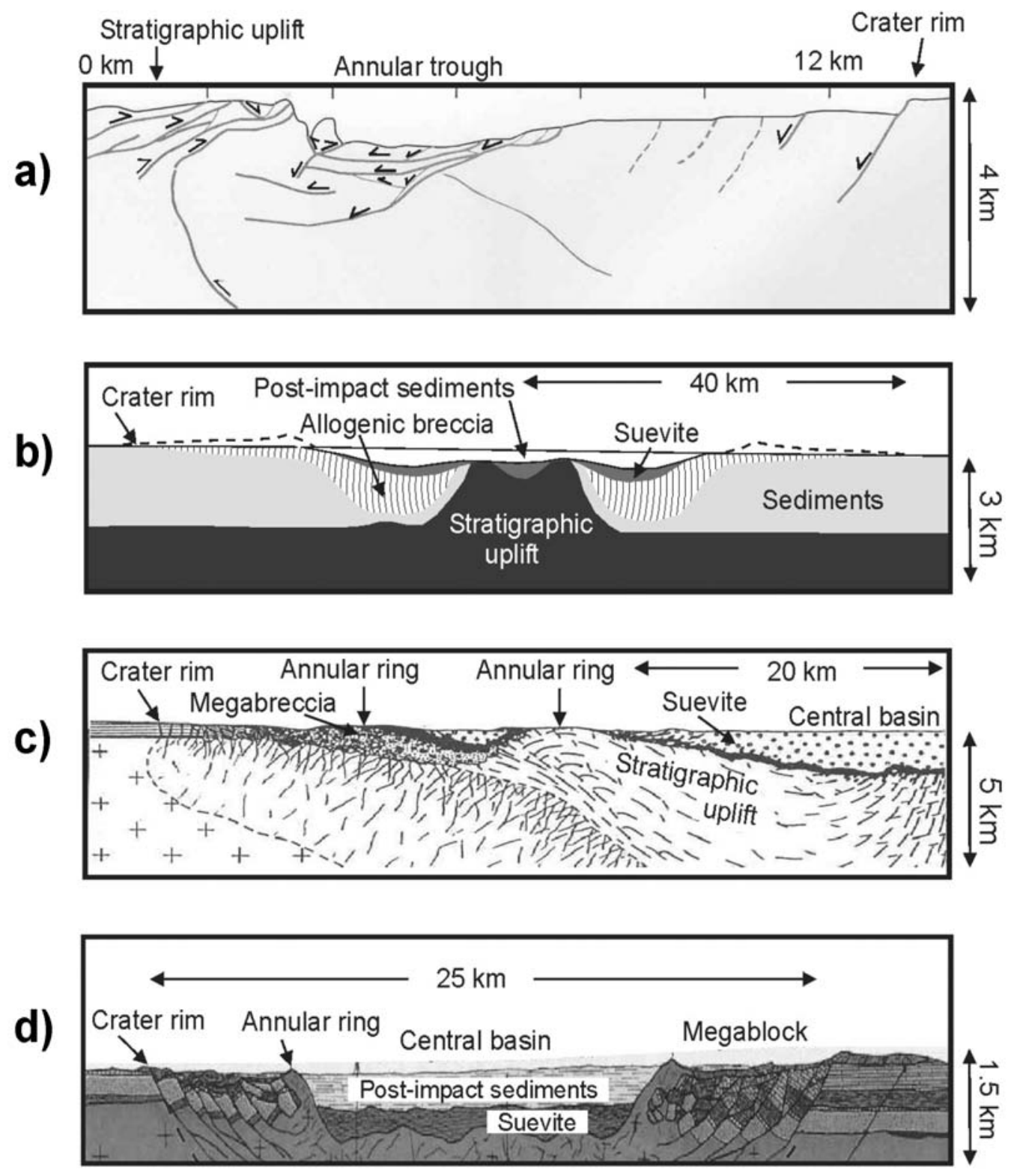

Fig. 3. a) The Rochechouart crater in France (after Kenkmann et al. 2000). The faults indicate the kinematics of crater collapse with subvertical collapse near the crater rim, inward sub-horizontal movement in material beneath the annular trough, and stratigraphic uplift moving upward and outward within the central crater. The collapse of the stratigraphic uplift outward above inward moving material is replicated in numerical modeling in Fig. 2b; b) Puchezh-Katunki crater, Russia (after Ivanov 1994). The stratigraphic uplift measured near the surface is $\sim 1 / 10$ the diameter of the final crater; c) Popigai crater, Russia (after Visnevsky and Montanari 1999). The stratigraphic uplift measured near the surface is $\sim 1 / 2$ the diameter of the final crater. There are two annular rings within the impact basin, and either could be the eroded remnant of a peak ring. The innermost ring is formed from stratigraphically uplifted material that has a concave top. The outer ring is formed from megabreccia, which is interpreted as material that has flowed along the base of the transient cavity during crater collapse; d) Ries Crater, Germany (after Pösges and Schieber 1994). The annular ring within this impact basin is the inner edge of the megablock zone. 
(Wünnemann et al. Forthcoming). A unique feature of modeling by Collins et al. (2002) is that the outwardcollapsing stratigraphic uplift actually overrides the inward collapsing rim to form a topographic peak ring (Fig. 2b). But, whether only the peak ring at Chicxulub formed this way or is a general mechanism for peak ring formation remains unproven. With regards to all numerical modeling, it is not easy to model the final spatial position of impact melts and breccias that are initially formed at or near the base of the transient cavity (shaded black in Fig. 2a) and that are then moved large distances during the subsequent collapse.

\section{TERRESTRIAL EXAMPLES}

\section{Stratigraphic Uplift}

A large number of terrestrial complex craters show stratigraphic uplift within the crater center, for example, Red Wing, Bosumtwi, Gosses Bluff, Manson, Mjølnir, Manicouagan, and Vredefort. The material that has been uplifted, the so called central uplift, can appear quite different in similar-sized craters. For example, the near-surface expression of the stratigraphic uplift in the $80 \mathrm{~km}$-diameter Puchezh-Katunki crater (Ivanov 1994; Deutsch et al. 2004) is relatively narrow and displays a central pit (Fig. 3b). In contrast, the $100 \mathrm{~km}$-diameter Popigai crater (Fig. 3c) has a relatively broad stratigraphic uplift that is roughly half the diameter of the final crater. The relative height of the stratigraphic uplift with respect to the pre-impact surface also appears variable and not directly correlated with crater size. For example, interpreted profiles across the Manson (Anderson et al. 1994), Mjølnir (Tsikalas et al. 1998), and Puchezh-Katunki (Fig. 3b) craters place the top of the uplift close to the pre-impact surface, while at both Ries (Fig. 3d) and Chicxulub, the uplift appears to be greater than $2 \mathrm{~km}$ beneath the pre-impact surface (e.g., Wünnemann et al. Forthcoming; Hildebrand et al. 1998).

\section{Peak Ring}

Scaling between planetary bodies suggests that peak rings should be observed in terrestrial craters with a diameter greater than $\sim 24 \mathrm{~km}$ (Pike 1983). However, only a small number of terrestrial craters display an annular ring inside the crater rim (e.g., Ries, Chesapeake, Clearwater West, Popigai, Mjølnir, and Chicxulub), and they do not all correspond to the same morphological element. At the Ries crater, the inner edge of the megablock zone, which is thought to represent the edge of the collapsed transient cavity, forms an inner ring (e.g., Pösges and Schieber 1994; Fig. 3d). The inner ring at Chesapeake (Poag et al. 2004) is likely to have the same origin, although, as it is buried beneath allogenic impact breccias, it cannot strictly be described as a topographic peak ring. The $100 \mathrm{~km}$-diameter Popigai crater, Russia (Visnevsky and Montanari 1999) displays two annular rings: a ring of uplifted basement and a ring of impact breccias (Fig. 3c). Which, if any, of these annular rings is a direct analogue of topographic peak rings on other planetary bodies remains uncertain.

\section{Allogenic Melt Rocks and Impact Breccias}

Terrestrial craters show distinct differences in the distribution of melt rocks and impact breccias, and these are also clearly related to the spatial position of the stratigraphic uplift. The $100 \mathrm{~km}$ Popigai crater (Fig. 3c) has a central basin containing suevite above a layer of melt rock that is several hundred meters thick, while the $>200 \mathrm{~km}$-diameter Sudbury impact basin contains suevitic layers on top of a thick intact melt sheet that has differentiated (e.g., Ostermann 1996). In some craters, the stratigraphic uplift appears to be surrounded by allogenic melt rocks or impact breccias (e.g., Manicouagan, Puchezh-Katunki; Fig. 3b), while in others, the stratigraphic uplift appears to solely underlie these breccias (e.g., Ries crater; Fig. 3d).

\section{Summary}

Similar-sized terrestrial craters can be quite different structurally. There is no clear progressive change in crater form with increasing size, and there is more than one type of annular ring within an impact basin. Although the current position of the stratigraphic uplift and allogenic impact rocks are likely to be affected by post-impact erosion, tectonic, and gravitational adjustments, it appears that some difference in the mechanics of crater formation is required to explain the observed differences in terrestrial crater profiles. One major influence on cratering mechanics on Earth is likely to be the target, as near-surface target rheology can change rapidly in both lateral and vertical directions. Grieve and Cintala (1999) and Grieve and Pesonen (1992) showed that impacts into crystalline targets produced more melt and larger depthdiameter ratios than impacts into sedimentary targets. Also, recent numerical modeling by Wünnemann et al. (Forthcoming) demonstrated that variations in the strength of a two-layered target can change the shape of the stratigraphic uplift and the nature of annular rings within the crater.

These observations suggest that we can expect certain structures and rock types within a large impact crater but cannot yet predict their geometry.

\section{GEOPHYSICAL DATA ACROSS CHICXULUB}

A range of geophysical data has been acquired across the crater, including gravity, magnetic, seismic reflection, seismic refraction, magnetotelluric data, and wireline logs. These data provide clues to the structure of the Chicxulub crater (Camargo-Zanoguera and Suárez-Reynoso 1994; Pilkington 
et al. 1994; Espindola et al. 1995; Sharpton et al. 1996; Campos-Enriquez et al. 1997; Hildebrand et al. 1998; Ebbing et al. 2001; Christeson et al. 1999; Morgan et al. 1997, 2002a, b). Using the geophysical data and drilling, Chicxulub is now widely agreed to be a $\sim 190 \mathrm{~km}$-diameter impact crater with a topographic peak ring (Morgan et al. 1997; Hildebrand et al. 1998; Dressler et al. 2003; Pope et al. 2004). A summary of the seismic-based constraints on the crater structure are shown in Fig. 1b. The seismic reflection data clearly image the impact basin, the peak ring, and the Cretaceous strata. However, the precise shape of the stratigraphic uplift, the nature of the peak ring, and the nature and extent of the allogenic deposits remain matters of some debate.

\section{Stratigraphic Uplift}

In the crater center, there is an anomalous zone that has a high seismic velocity $\left(>6.2 \mathrm{kms}^{-1}\right)$, a high density, and a strong magnetic signature (Fig. 1b). In the majority of geophysical-based interpretations of the Chicxulub crater, this anomalous zone has been interpreted as stratigraphic uplift (and is often referred to as central uplift). This is at least in part based on the expectation that stratigraphic uplift occurs at complex craters. In support of this interpretation, the high velocities $\left(>6.2 \mathrm{kms}^{-1}\right)$ indicate a deep-crustal lithology rather than a sedimentary one, and the concave-upward shape of the velocity anomaly is similar in shape to the uplift at the Puchezh-Katunki and Popigai craters (Figs. $3 b$ and $3 c$ ). The only other plausible explanation for such high velocities is that they are differentiated melt rocks at the base of an intact melt sheet and are similar in origin to the norite layer at Sudbury. Models of the shape of the stratigraphic uplift at Chicxulub, which are principally based on potential-field data (e.g., Pilkington et al. 1994; Ebbing et al. 2001), show the central uplift with a flat top and an increase in width with depth. Hildebrand et al. (2003) asserted that the interpretation of the shape of the stratigraphic uplift by Morgan et al. (2000), as shown in Fig. 1b, was incorrect. Although they had not undertaken any modeling to test this assertion, they suggested that, on conversion from velocity to density, the resulting density model would not fit the gravity data. For this reason, we have tested whether or not the proposed velocity model is consistent with the gravity data, and the results are presented in the next section.

\section{Peak Ring}

The diversity in the nature of annular rings in terrestrial examples has led to contradictory interpretations on the nature of the peak ring at Chicxulub. Pilkington et al. (1994) interpreted the peak ring as being formed by allogenic breccia and placed it to coincide with a $70 \mathrm{~km}$-diameter gravity low. In contrast, Sharpton et al. (1996) concluded that the peak ring was an annular ring of uplifted basement material (as observed at the Popigai crater; Fig. 3c) and located it to coincide with a $100 \mathrm{~km}$-diameter gravity high. Seismic reflection data have subsequently identified the peak ring to have an $80-85 \mathrm{~km}$ diameter and to be unrelated to a specific gravity anomaly (Morgan et al. 1997; Hildebrand et al. 1998).

If the interpretation of the seismic reflection data is correct (Fig. 1b), the peak ring at Chicxulub lies several km directly above target sediments. This suggests that the peak ring is unlikely to correspond to the inner edge of the collapsed transient cavity rim (the annular ring observed at the Ries crater; Fig. 3d). The peak ring at Chicxulub is coincident with an inward dipping low-velocity-zone (LVZ) (Fig. 1b; Morgan et al. 2000). A low-velocity peak ring is more likely to be formed from megabreccia (illustrated in Fig. 3c) than from uplifted basement rock. If this is true, then among large terrestrial impact craters, Chicxulub appears be the most similar to Popigai, with a concave-upward stratigraphic uplift, a peak ring formed from impact breccia, and an inward dipping boundary that represents the contact between an outwardly collapsed stratigraphic uplift and an inwardly collapsed transient cavity rim (compare Figs. 1b, 2b, and $3 \mathrm{c}$ ). We know that the collapsing stratigraphic uplift moves outward and will, at some point, interact with the inward collapsing transient cavity rim (Fig. 2b). Possibly, at Chicxulub and Popigai, breccias moving along the wall of the transient cavity were squeezed upward when these two collapse regimes met.

\section{Allogenic Melt Rocks and Impact Breccias}

The precise distribution of the impact breccias and melt rocks is poorly constrained at Chicxulub because of the lack of drill holes below a depth of $1.63 \mathrm{~km}$ and the unknown geophysical signature of these deposits. Some models include an impact melt sheet that surrounds the central uplift (Pilkington et al. 1994; Ebbing et al. 2001) - a geometry that is suggested in the outcrop at the Manicouagan crater. Sharpton et al. (1996) proposed that there was a melt-rich suevitic layer in the crater center, similar to that observed at Popigai, rather than a thick, intact melt sheet. Some models also place melt rocks within the annular trough (Sharpton et al. 1996; Ebbing et al. 2001). Much of the central region has been left uninterpreted in Fig. $1 b$ to reflect the level of uncertainty.

\section{DATA AND INITIAL RESULTS}

\section{Physical Measurements}

The Yax-1 well (see Fig. 1 for location) penetrated about $800 \mathrm{~m}$ of Tertiary rocks, $\sim 100 \mathrm{~m}$ of impact breccias, and $\sim 600 \mathrm{~m}$ of Cretaceous rocks (Dressler et al. 2003). The well was cored between depths of 404 and $1511 \mathrm{~m}$. For this study, 18 samples were selected, seen as representative for each lithology (Table 1). Where possible, only homogeneous and 
Table 1. Sample identifier with depth of recovery (in $\mathrm{m}$ ), lithology unit, and stratigraphic position for 18 samples from the Yax-1 core. $^{\mathrm{a}}$

\begin{tabular}{lll}
\hline Sample identifier & Lithology unit & Stratigraphic position \\
\hline Yax-1_407.118 & Carbonaceous siltstone-limestone & Tertiary \\
Yax-1_407.364 & Carbonaceous siltstone-limestone & Tertiary \\
Yax-1_455.965 & Carbonaceous siltstone-limestone & Tertiary \\
Yax-1_553.080 & Carbonaceous siltstone-limestone & Tertiary \\
Yax-1_600.010 & Carbonaceous siltstone-limestone & Tertiary \\
Yax-1_655.340 & Limestone & Tertiary \\
Yax-1_757.770 & Paraconglomerate & Tertiary \\
Yax-1_775.440 & Orthoconglomerate & Tertiary \\
Yax-1_796.620 & Redeposited suevite & Impact breccia \\
Yax-1_908.610 & Limestone & Cretaceous \\
Yax-1_986.000 & Calcarenite & Cretaceous \\
Yax-1_1005.370 & Calcarenite & Cretaceous \\
Yax-1_1055.380 & Calcarenite-anhydrite & Cretaceous \\
Yax-1_1152.480 & Calcarenite-anhydrite & Cretaceous \\
Yax-1_1247.130 & Dolomite breccia & Cretaceous \\
Yax-1_1383.300 & Dolomite breccia & Cretaceous \\
Yax-1_1443.810 & Dolomite-anhydrite & Cretaceous \\
Yax-1_1497.970 & Dolomite breccia & Cretaceous \\
\hline
\end{tabular}

${ }^{a}$ Lithology taken from: http://www.icdp-online.de.

fine-grained cores without cracks or veins were chosen to provide optimum test conditions for the measurement of $\mathrm{P}$ and $\mathrm{S}$ wave velocities.

\section{Sample Acquisition and Laboratory Preparation}

A total of 18 cylindrical plugs of $\sim 25 \mathrm{~mm}$ in diameter were cored from the larger samples. Water was employed as a drilling fluid for 15 samples, and ethylene glycol was used in the case of the two more reactive samples (Yax-1_1152.480 and Yax-1_1383.300). The highly reactive suevite breccia sample, Yax-1_796.620, was drilled using a water-based lubricating oil to avoid disintegration during preparation and was subsequently cleaned using toluene. The plugs were then cut to a length of between 22 and $47 \mathrm{~mm}$, and their ends were ground parallel using a tollroom surface grinder. All test specimens were drilled parallel to the vertical axis of the core, except sample Yax-1_796.620, which was drilled perpendicular to the axis after several attempts to obtain a vertically oriented core failed.

The specimens were dried for 3 days in an oven maintained at $60{ }^{\circ} \mathrm{C}$ to remove pore fluids from interconnected and open-ended pores and any fluid left from the drilling process. Dry bulk density values (Table 2 ) were derived from dividing the mass of the dry specimens by the bulk volume calculated from their cylinder geometry and dimensions. For samples with imperfect cylinder geometry, bulk volume was measured after saturating the samples, using the water displacement method to determine the volume of an irregularly shaped object. Helium gas porosimetry was used to determine the grain volume, and this was then used to calculate the grain density and porosity of each specimen
(Table 2). After the measurement of ultrasonic velocities on the dry samples, the specimens were transferred to a vacuum saturator, where they were saturated for $24 \mathrm{hr}$ with de-aired $3.3 \mathrm{wt} \% \mathrm{NaCl}$ brine to simulate down hole conditions. The composition of the brine assumes the presence of seawater in the pore spaces of the rocks, representative of deposition in a marine environment. Complete saturation was achieved by leaving the plugs in the brine for $24 \mathrm{hr}$ under $7 \mathrm{MPa}$ pressure. The saturated samples were weighed, and the saturated bulk density was calculated (Table 2). Ultrasonic velocity and fluid permeability measurements where then made on the brinesaturated specimens.

\section{Ultrasonic Velocity Measurements}

The ultrasonic test system is described in detail by King and Shams-Khanshir (1998). The system permits the measurement of the velocities of ultrasonic compressional $(\mathrm{P})$ and shear (S) waves with an accuracy of better than $\pm 1.0 \%$ and a precision of $\pm 0.5 \%$ for plugs with lengths of $\sim 45 \mathrm{~mm}$ (King and Shams-Khanshir 1998). Transmitting and receiving transducer holders are mounted at each end of the cylindrical rock specimen. A pulsing unit is used to excite, in turn, the combined $\mathrm{P}$ and $\mathrm{S}$ wave transmitting transducers and to provide a trigger pulse to the time base of the digital oscilloscope. The energy pulses are transmitted axially through the specimen, with pulse train bandwidths of 500-900 $\mathrm{kHz}$ for the $\mathrm{P}$ waves and $300-700 \mathrm{kHz}$ for the $\mathrm{S}$ waves. The waveforms are amplified and monitored in the time-domain with an oscilloscope in addition to being digitally recorded. The first arrivals of the $\mathrm{P}$ and $\mathrm{S}$ waves are picked manually, and the time-of-flight of the ultrasonic pulse from the 
Table 2. Measured porosity $(\phi)$, permeability $(\mathrm{K})$, grain density $\left(\rho_{\mathrm{o}}\right)$, and dry and saturated bulk density $\left(\rho_{\mathrm{b}}\right)$ on 18 samples from the Yax-1 core, and average bulk density $\left(\rho_{\mathrm{b}}\right)$. (See discussion in the text.)

\begin{tabular}{lclllll}
\hline Sample identifier & $\phi(\%)$ & $\mathrm{K}(\mathrm{mD})$ & $\begin{array}{l}\rho_{\mathrm{o}} \\
\left(\mathrm{g} / \mathrm{cm}^{-3}\right)\end{array}$ & $\begin{array}{l}\text { Dry } \rho_{\mathrm{b}} \\
\left(\mathrm{g} / \mathrm{cm}^{-3}\right)\end{array}$ & $\begin{array}{l}\text { Saturated } \rho_{\mathrm{b}} \\
\left(\mathrm{g} / \mathrm{cm}^{-3}\right)\end{array}$ & $\begin{array}{l}\text { Average } \rho_{\mathrm{b}} \\
\left(\mathrm{g} / \mathrm{cm}^{-3}\right)\end{array}$ \\
\hline Yax-1_407.118 & 8 & 0.001 & 2.73 & 2.51 & 2.59 & 2.08 \\
Yax-1_407.364 & 29 & 0.001 & 2.57 & 1.83 & 2.11 & 2.08 \\
Yax-1_455.965 & 16 & 0.01 & 2.69 & 2.26 & 2.42 & 2.11 \\
Yax-1_553.080 & 24 & 0.007 & 2.35 & 1.79 & 2.00 & 2.16 \\
Yax-1_600.010 & 28 & 0.002 & 2.50 & 1.80 & 2.08 & 2.18 \\
Yax-1_655.340 & 30 & 5.0 & 2.68 & 1.88 & 2.19 & 2.21 \\
Yax-1_757.770 & 29 & 1.9 & 2.67 & 1.89 & 2.18 & 2.26 \\
Yax-1_775.440 & 7 & 0.003 & 2.71 & 2.51 & 2.58 & 2.27 \\
Yax-1_796.620 & 24 & - & 2.63 & 1.92 & 2.24 & 2.24 \\
Yax-1_908.610 & 11 & 1.5 & 2.70 & 2.39 & 2.50 & 2.20 \\
Yax-1_986.000 & 9 & 0.02 & 2.76 & 2.52 & 2.60 & 2.62 \\
Yax-1_1005.370 & 9 & 0.02 & 2.80 & 2.55 & 2.64 & 2.62 \\
Yax-1_1055.380 & 0.5 & 0.9 & 2.95 & 2.94 & 2.94 & 2.58 \\
Yax-1_1152.480 & 17 & 0.8 & 2.66 & 2.20 & 2.38 & 2.76 \\
Yax-1_1247.130 & 0.6 & 1.0 & 2.95 & 2.93 & 2.94 & 2.76 \\
Yax-1_1383.300 & 17 & 2.6 & 2.81 & 2.33 & 2.50 & 2.66 \\
Yax-1_1443.810 & 0.2 & 1.1 & 2.95 & 2.94 & 2.95 & 2.78 \\
Yax-1_1497.970 & 3 & 0.00005 & 2.68 & 2.62 & 2.64 & 2.78 \\
\hline
\end{tabular}

transmitter to the receiver is measured using the oscilloscopecalibrated time base. The ultrasonic $\mathrm{P}$ and $\mathrm{S}$ wave velocities $\left(\mathrm{V}_{\mathrm{P}}\right.$ and $\left.\mathrm{V}_{\mathrm{S}}\right)$ are calculated by dividing the specimen length, which is monitored throughout each test, by the time-of-flight of the pulse through the specimen. The latter is obtained by subtracting the time-of-flight through the transducer holders in face-to-face contact from the total measured time.

In these measurements, the axial and confining stresses were maintained equal to provide hydrostatic test conditions. The first velocities were acquired at a stress of $1 \mathrm{MPa}$, and subsequent measurements were made in steps of $5 \mathrm{MPa}$ up to 15,20 , or $25 \mathrm{MPa}$ (Fig. 4), depending on the depth at which the core was recovered. Measuring velocities at each step of increasing applied stress enables the estimation of $V_{P}$ and $V_{S}$ for each lithology at various depths below the surface. To avoid permanent damage to the sample in the form of crushing at the grain contact, the applied stress never exceeded the effective stress representative of in situ conditions by more than $5 \mathrm{MPa}$.

\section{Results}

The results of the porosity and permeability measurements are summarized in Table 2. Measured porosities are very variable and range from between $<1 \%$ and $30 \%$. Large differences exist between samples from the same lithological unit. Fluid permeabilities are extremely low with values $<0.1 \mathrm{mD}$ for nine samples and a maximum value of $5 \mathrm{mD}$ in limestone sample Yax-1_655.340. Since our sample selection was biased toward choosing homogeneous and finegrained samples without cracks or veins, these low permeabilities may be atypical of the core in general.
All calculated dry and brine-saturated $\mathrm{P}$ and $\mathrm{S}$ wave velocities $\left(\mathrm{V}_{\mathrm{P}}\right.$ and $\left.\mathrm{V}_{\mathrm{S}}\right)$ were plotted as a function of applied stress, and, for each, a best-fit logarithmic regression curve was determined (Fig. 4). Brine-saturated measurements could not be made on the suevite sample Yax-1_796.620 because of its high reactivity. The bulk density measurement for sample Yax-1_796.620 in Table 2 is calculated using the grain density and porosity and assuming that the pore space is filled with a fluid of density of $1.023 \mathrm{~g} / \mathrm{cm}^{-3}$. As expected, the $\mathrm{V}_{\mathrm{S}}$ for the dry rock is higher than that for the saturated rock in all samples (Fig. 4). The logarithmic regression curves for $V_{P}$ behave in various ways. For samples Yax-1_908.610 (Fig. 4a), Yax-1_1497.970, Yax-1_1247.130, and Yax1_775.440, the saturated $V_{P}$ is higher than the dry $V_{P}$ at the same applied stress. Most other samples, however, exhibit the opposite behavior, with the saturated $\mathrm{V}_{\mathrm{P}}$ being slightly lower than the dry $V_{P}$ (e.g., Fig. 4b). Variations to these two kinds of $\mathrm{V}_{\mathrm{P}}$ behavior exist in the two logarithmic regression curves crossing over at an applied stress of less than $6 \mathrm{MPa}$. The different behaviors for dry and saturated $V_{P}$ reflect the relative changes in bulk modulus and density with changes in pressure, which themselves depend on crack shape and orientation (e.g., Tao et al. 1995). The difference between dry and brine-saturated $V_{P}$ does not exceed values of $0.5 \mathrm{kms}^{-1}$, while the maximum difference for $V_{S}$ is $0.7 \mathrm{kms}^{-1}$.

Figure 5 is a plot of $V_{P}$ versus $V_{S}$, with all velocities measured at an applied stress of $15 \mathrm{MPa}$. A linear regression provides the relationships: $\mathrm{V}_{\mathrm{S}}=0.600 \mathrm{~V}_{\mathrm{P}}+0.002$, with $\mathrm{R}^{2}=$ 0.97 for the oven-dried samples, and $\mathrm{V}_{\mathrm{S}}=0.523 \mathrm{~V}_{\mathrm{P}}-0.031$, with $R^{2}=0.95$ for the brine-saturated samples, with $V_{P}$ and $V_{S}$ expressed in $\mathrm{kms}^{-1}$. Both dry and saturated linear regression curves lay below the commonly reported relationship between 

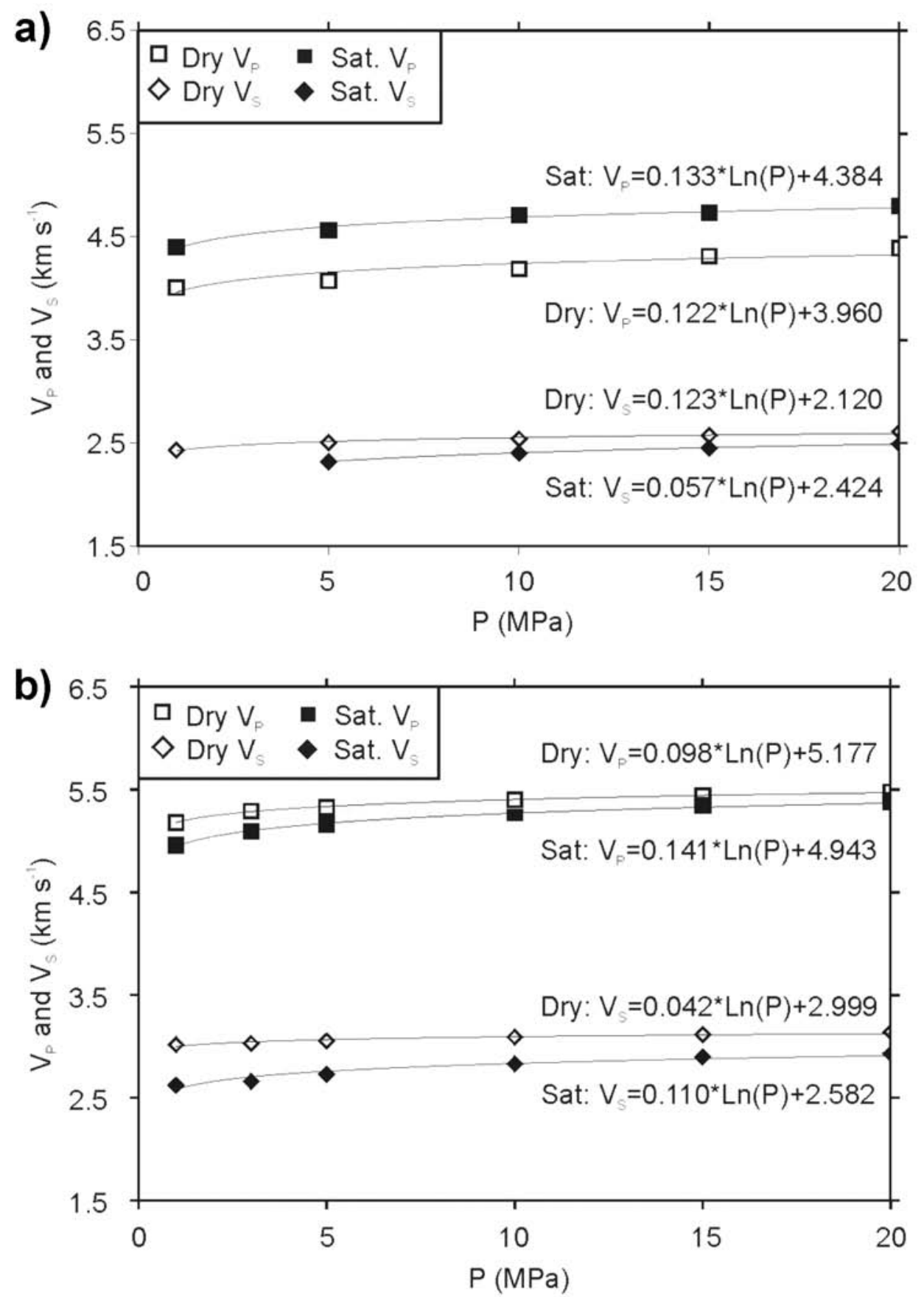

Fig. 4. a) $\mathrm{P}$ and $\mathrm{S}$ wave velocities versus applied stress (P) for dry (open symbols) and brine-saturated (closed symbols) limestone sample Yax1_908.610, with logarithmic regression curves of the measurements; b) P and S wave velocities versus applied stress (P) for dry (open symbols) and brine-saturated (closed symbols) calcarenite sample Yax-1_986.000, with logarithmic regression curves of the measurements.

$\mathrm{P}$ and $\mathrm{S}$ wave velocity of $\mathrm{V}_{\mathrm{S}}=0.667 \mathrm{~V}_{\mathrm{P}}$. The empirical relationship $\mathrm{V}_{\mathrm{S}}=0.526 \mathrm{~V}_{\mathrm{P}}$ (Picket 1963), which holds extremely well for clean limestones with $\mathrm{V}_{\mathrm{S}}$ greater than 1.5 $\mathrm{kms}^{-1}$ (Castagna et al. 1993), and the empirical relationship for dolomite, $\mathrm{V}_{\mathrm{S}}=0.583 \mathrm{~V}_{\mathrm{P}}-0.078$ (Castagna et al. 1993), are also plotted. The regression curve for brine-saturated samples is in fairly good agreement with Picket's relationship for limestone and differs from Castagna's relationship for dolomite.
In Fig. 6, oven-dried and brine-saturated $V_{P}$ and $V_{S}$ at $15 \mathrm{MPa}$ are plotted as a function of the corresponding dry and saturated bulk density $\left(\rho_{\mathrm{b}}\right)$, respectively (Table 2$)$. A linear regression was fitted to the saturated values providing the following relationships: $V_{P}=3.928 \rho_{b}-5.155$, with $R^{2}=$ 0.93 , and $\mathrm{V}_{\mathrm{S}}=1.997 \rho_{\mathrm{b}}-2.583$, with $\mathrm{R}^{2}=0.83$. The polynomial forms of the Gardner et al. (1974) velocitydensity relationships for limestone and dolomite, presented 


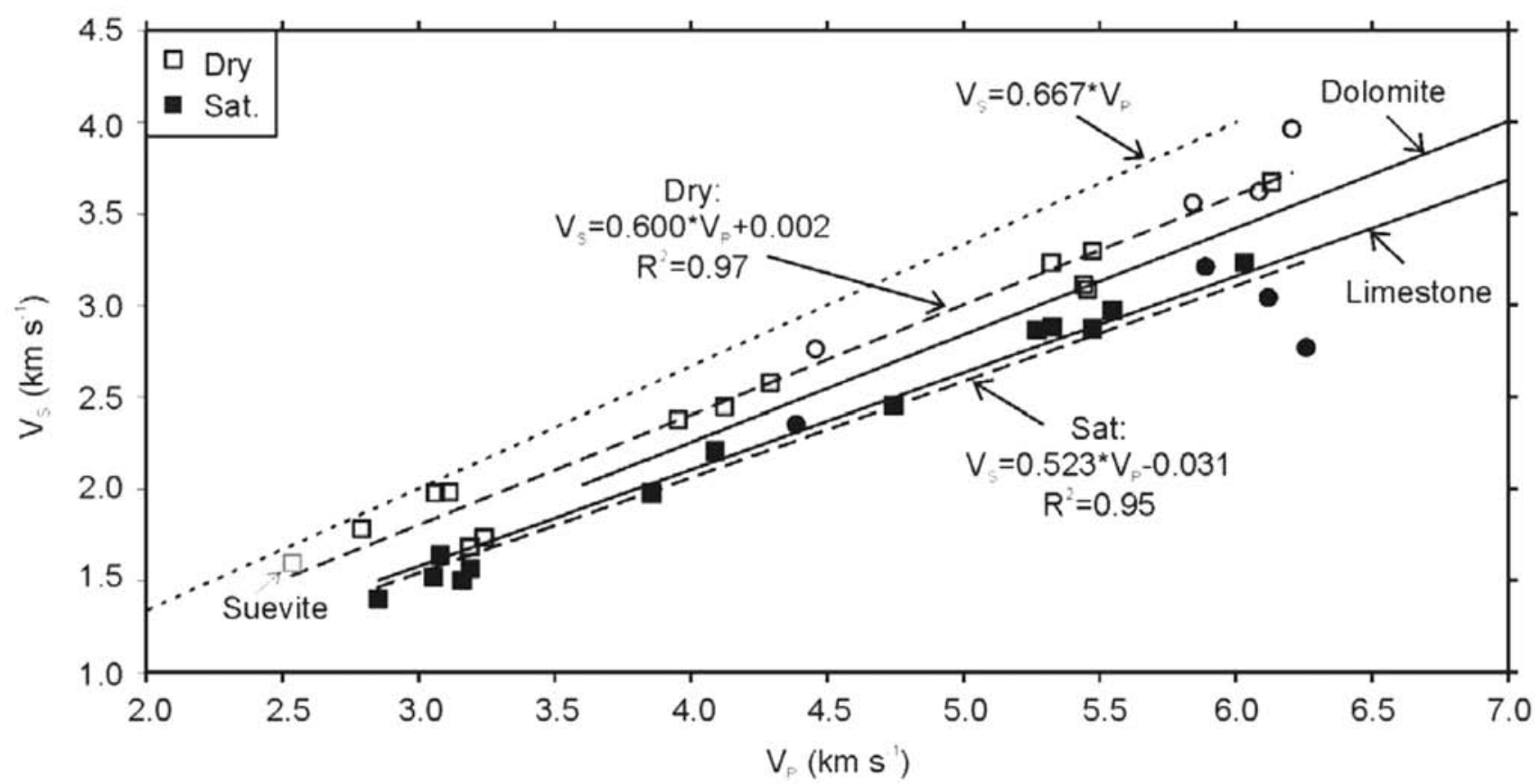

Fig. 5. Dry (open symbols) and brine-saturated (closed symbols) $V_{P}$ versus $V_{S}$ measured at an applied stress of $15 \mathrm{MPa}$, with linear regression curves of the measurements (dashed lines). The measurements of samples containing dolomite are plotted as circles, and the measurement of the redeposited suevite sample Yax-1_796.620 is indicated in gray (suevite). Also shown are the empirical relationships between $V_{P}$ and $V_{S}$ for limestone and dolomite (solid lines) of Picket (1963) and Castagne et al. (1993), respectively, and the commonly reported relationship $\mathrm{V}_{\mathrm{S}}$ $=0.667 \mathrm{~V}_{\mathrm{P}}$ (dotted line).

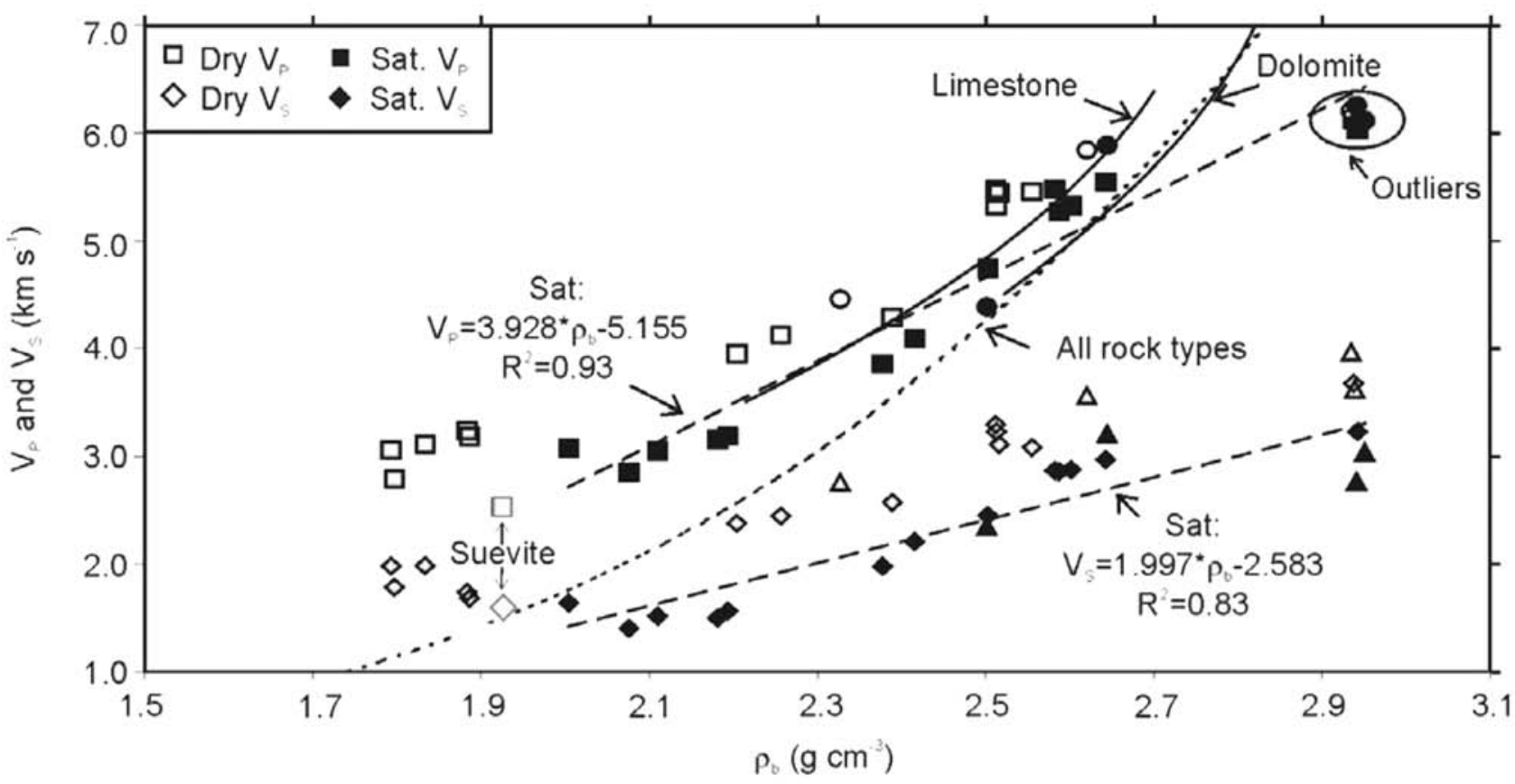

Fig. 6. Dry (open symbols) and brine-saturated (closed symbols) $\mathrm{V}_{\mathrm{P}}$ (squares and circles) and $\mathrm{V}_{\mathrm{S}}$ (diamonds and triangles) measured at an applied stress of $15 \mathrm{MPa}$ versus dry and saturated bulk density, respectively, with linear regression curves of the brine-saturated measurements (dashed lines). The measurements of samples containing dolomite are plotted as circles and triangles for $V_{P}$ and $V_{S}$, respectively, and the measurements of the redeposited suevite sample Yax-1_796.620 are indicated in gray (suevite). Also shown are the second-order polynomial forms of the Gardner et al. (1974) $\mathrm{V}_{\mathrm{p}}$-density relationships for limestone and dolomite (solid curves), presented by Castagna et al. (1993), and the Gardner et al. (1974) average $\mathrm{V}_{\mathrm{P}}$-density relationship for all rock types (dotted curve). The three outliers discussed in the text are also indicated. 
by Castagna et al. (1993), are also plotted. The presented results follow the relationship for limestone well except for three outliers (indicated in Fig. 6) with very high bulk density, consisting of dolomite breccia (Yax-1_1247.130), dolomiteanhydrite (Yax-1_1443.810), and calcarenite-anhydrite (Yax1_1055.380). For the brine-saturated $\mathrm{P}$ wave velocities, the measured bulk rock densities are within $6 \%$ of those predicted by the linear regression curve.

The logarithmic regression curves are used to calculate $V_{P}$ and $V_{S}$ of each sample at the effective stress (P) corresponding to the depth at which the sample was recovered (Table 3). The in situ effective stress was calculated by subtracting the hydrostatic stress (or pore pressure) from the overburden (or lithostatic stress) and using the assumption that the rocks are normally pressured and fully saturated with $3.3 \mathrm{wt} \% \mathrm{NaCl}$ brine. For the calculation of lithostatic stress, an average bulk density for each core interval (last column in Table 2) was derived from various sources. At the projected position of Yax-1 onto seismic line Chicx-A (Fig. 1a), seismic refraction velocities within the Tertiary section gradually increase from 2.3 to $3.9 \mathrm{kms}^{-1}$ (Christeson et al. 1999). Using the regression curve for our core measurements (Fig. 6) gives an increase in bulk density from $\sim 1.9 \mathrm{~g} / \mathrm{cm}^{-3}$ at the surface to $\sim 2.3 \mathrm{~g} / \mathrm{cm}^{-3}$ at the base of the Tertiary. The bulk density of the impact breccias is set to $2.24 \mathrm{~g} / \mathrm{cm}^{-3}$, as measured from the suevite breccia sample Yax-1_796.620. The Cretaceous rocks below the impact series are highly variable in lithology and sonic velocity. An average bulk density was assigned to the different lithological units in the Cretaceous section (Table 2), and lithostatic and effective stress at a particular depth was calculated accordingly (first column in Table 3). Average bulk densities were derived using two methods: sonic velocities combined with rock type, using the Gardner et al. (1974) velocitydensity relationships, and averaging of laboratory measurements on the specimens. The comparison of the average bulk densities used in the lithostatic stress calculation with the measured saturated bulk densities of the individual specimens (Table 2) shows that all specimen densities are within $24 \%$ of those predicted by the seismic refraction and sonic velocity data in the corresponding lithological unit. Although the single bulk density measurement of the suevite breccia sample Yax-1_796.620 may not be representative of the whole series of impact breccias, within the range of possibilities, its value has a negligible effect on the calculated $\mathrm{V}_{\mathrm{P}}$ and $\mathrm{V}_{\mathrm{S}}$ of each sample at in situ conditions.

From the velocity values at in situ effective stress, the Poisson's ratios are calculated for dry and brine-saturated samples (Fig. 7). The dry values range considerably between 0.13 and 0.33 , while the brine-saturated values are within a smaller range of 0.29 to 0.38 , with a mean value of 0.32 . The brine-saturated $V_{P}$ values at in situ effective stress are plotted for comparison with the sonic log data acquired in the deepest section of the Yax-1 hole (Fig. 8). Most samples have velocity values well within the scatter of the wireline log data, except dolomite breccia samples Yax-1 1383.300 and Yax1 1497.970. Possible reasons for the deviation in sonic and measured velocities are: velocity dispersion, incorrect effective stress estimation combined with a high velocity versus stress gradient, or the sample is not representative of this lithological unit. The measured $\mathrm{V}_{\mathrm{P}}$ of brine-saturated sample Yax-1_1247.130 shows very good agreement with the near-constant high sonic $V_{P}$ through the $\sim 100$ m-thick dolomite breccia unit.

Table 3. Calculated effective stress representative of in situ conditions $(\mathrm{P})$ at the depth at which the sample was recovered and measured dry and brine-saturated $\mathrm{V}_{\mathrm{P}}$ and $\mathrm{V}_{\mathrm{S}}$.

\begin{tabular}{llllll}
\hline & $\begin{array}{l}P \\
\text { Sample identifier }\end{array}$ & $\begin{array}{l}\text { Dry } \mathrm{V}_{\mathrm{P}} \\
(\mathrm{kms})\end{array}$ & $\begin{array}{l}\text { Dry } \mathrm{V}_{\mathrm{S}} \\
\left(\mathrm{kms}^{-1}\right)\end{array}$ & $\begin{array}{l}\text { Saturated } \mathrm{V}_{\mathrm{P}} \\
\left(\mathrm{kms}^{-1}\right)\end{array}$ \\
\hline Yax-1_407.118 & 3.91 & 5.28 & 3.44 & 5.25 & 2.89 \\
$\left(\mathrm{kms}^{-1}\right)$
\end{tabular}




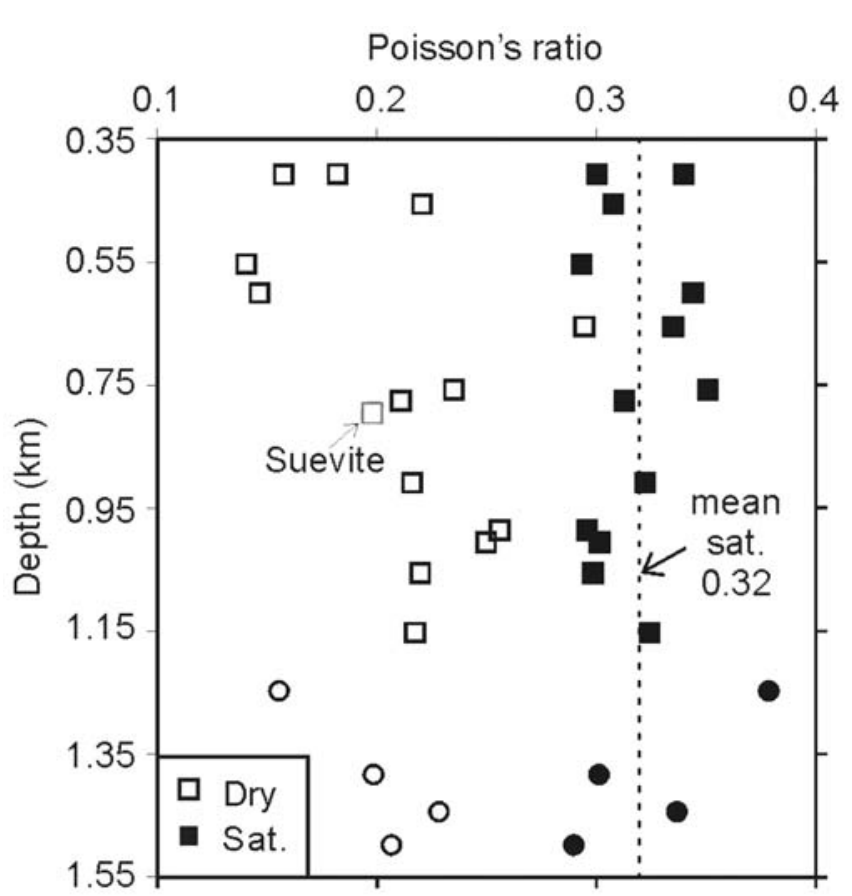

Fig. 7. Poisson's ratios versus depth for dry (open symbols) and brine-saturated (closed symbols) samples. A mean value of 0.32 was obtained for the brine-saturated samples. Measurements of samples containing dolomite are plotted as circles, and the measurement of the redeposited suevite sample Yax-1_796.620 is indicated in gray (suevite).

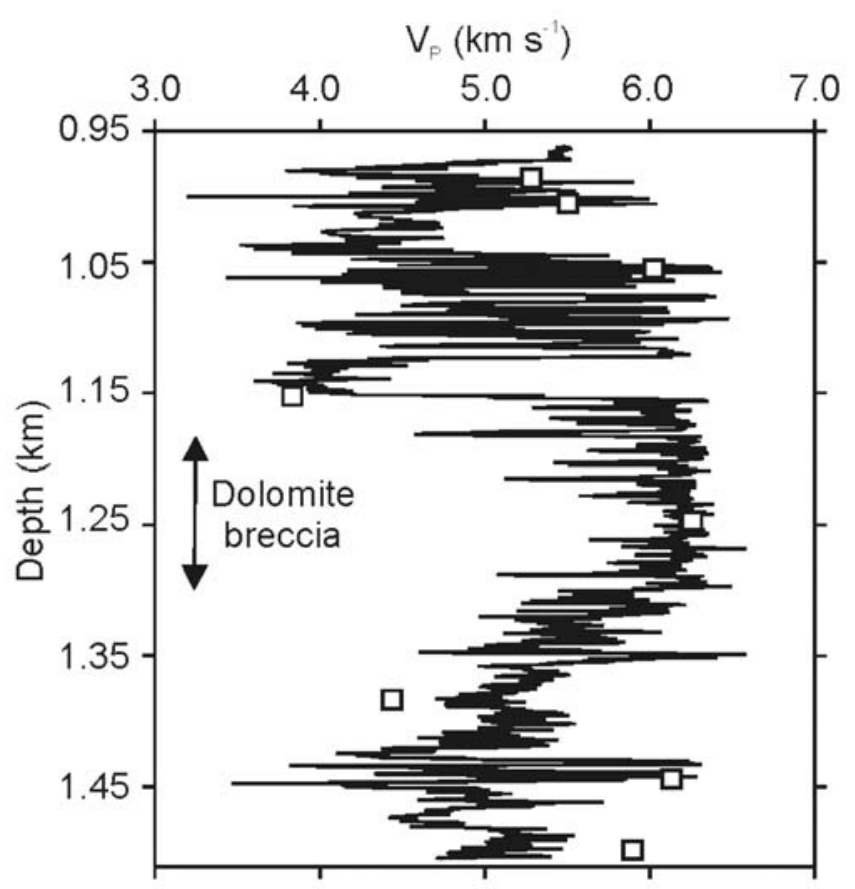

Fig. 8. Sonic log velocities (solid line) in the lower half of borehole Yax-1. Open squares show measured brine-saturated ultrasonic Pwave velocities of samples at in situ conditions (Table 3 ).

\section{GRAVITY MODELING}

One of our aims is to produce a lithological and structural model of Chicxulub that is consistent with the combined geophysical data. In this section, we focus on the central crater and examine whether or not the $3 \mathrm{D}$ velocity data is consistent with the gravity data.

The velocity model presented in Morgan et al. (2000, 2002a) originates from a 3D refraction experiment, with $\sim 500,000$ travel-time picks as input to the 3D tomographic inversion of Zelt and Barton (1998). Velocity models from 3D refraction data are superior to $2 \mathrm{D}$ models because each velocity cube is sampled by ray paths crossing in many different directions. The travel-times were picked independently by researchers at both the University of Texas at Austin and Imperial College (London), and a suite of inversions were run at both institutions. The robustness of the inverted velocity models is illustrated by their virtual independence of the starting model (Morgan et al. 2000, 2002a), and structureless 1D starting models were used as input to these inversions. The resolution of the velocity models has been properly tested at different depths and spatial locations (Morgan et al. 2002a) using the procedures outlined in Zelt (1998). Hence, we are certain that the main features of the velocity data shown in Fig. 1b. are real: the concave upward shape of the top of the high-velocity-zone and the inward dipping low-velocity-zone beneath the peak ring.

We have taken a $2 \mathrm{D}$ slice through the $3 \mathrm{D}$ velocity tomogram, along a line parallel to seismic lines Chicx-A and -D (Fig. 1a), on a bearing of $\sim 077^{\circ}$ through the nominal crater center $(89.54 \mathrm{~W}$ and $21.3 \mathrm{~N})$. This particular profile was chosen to be as close to Yax-1 as possible but to remain in a region where the velocity data is still well-constrained (see Fig. 1a). The velocity data show a high-velocity-zone with a concave top that dips from west to east. We have used this velocity data to guide our gravity modeling - our best guess for the shape of the top of the stratigraphic uplift is shown in model 1 in Fig. 9. The relative increase in velocity within the stratigraphic uplift of $0.4-0.6 \mathrm{kms}^{-1}$ (Morgan et al. 2002a) suggests a relative density increase of $0.1-0.15 \mathrm{~g} / \mathrm{cm}^{-3}$ (Fig. 6; Gardner et al. 1974), which is consistent with other density models across Chicxulub (Pilkington et al. 1994; Espindola et al. 1995; Ebbing et al. 2001). Along this particular profile, the velocity data is poorly resolved at shallow depths outside the stratigraphic uplift (Morgan et al. 2002a) but, on better-resolved profiles, we see an inward dipping low-velocity-zone (LVZ) (Fig. 1b), and we model these zones with a negative density contrast of $-0.1 \mathrm{~g} / \mathrm{cm}^{-3}$ (see Fig. 9). We have modeled the data in $2.5 \mathrm{D}$, and each feature has an appropriate strike length.

Model 1 in Fig. 9 represents one of a range of models that is consistent with the velocity data and also fits the gravity data. The gravity data can be modeled equally well with a less dense stratigraphic uplift that lies closer to the surface or a 


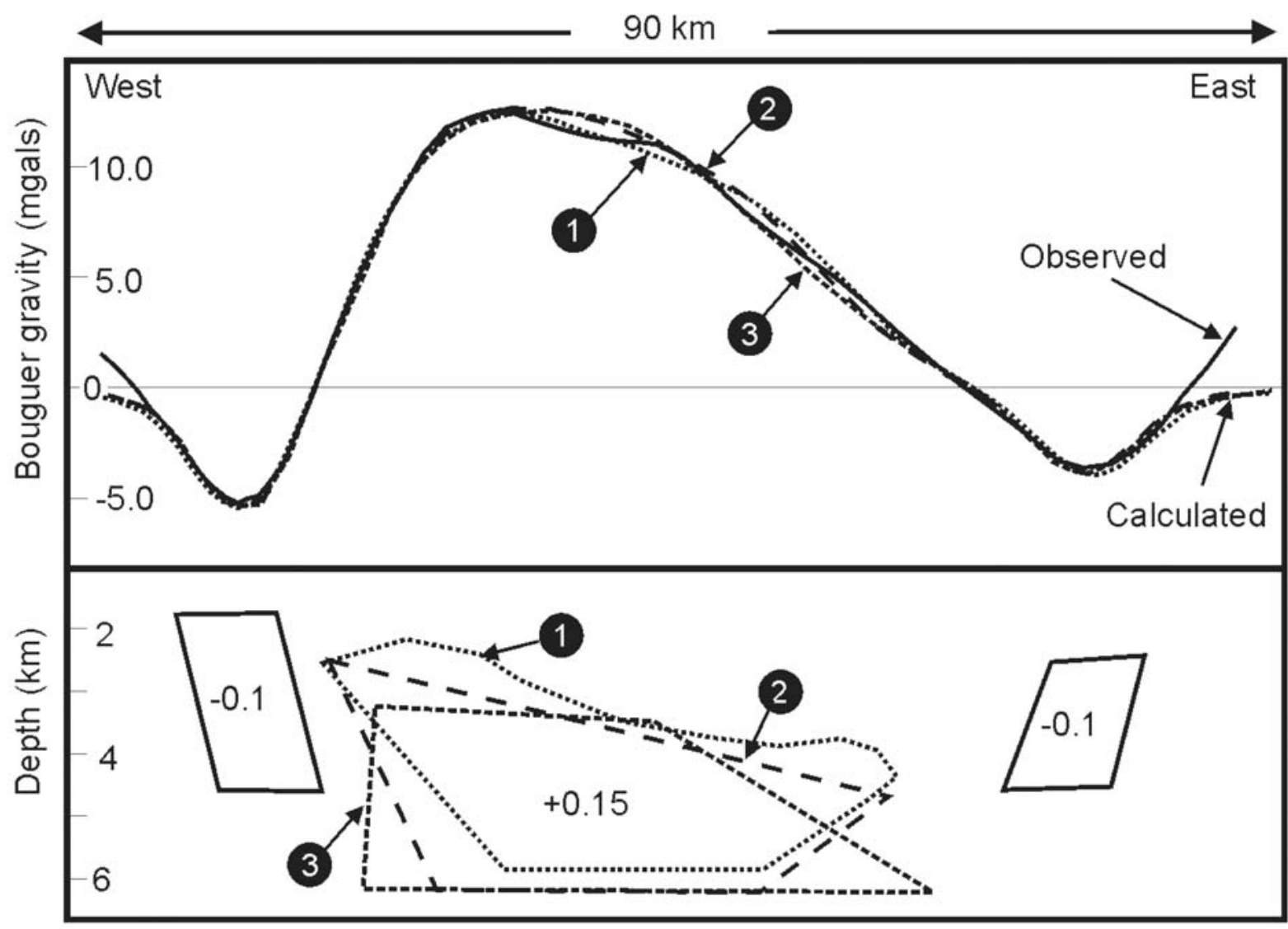

Fig. 9. Observed and calculated gravity data for three density models of the central crater. Observed gravity has been taken along a line parallel to seismic lines Chicx-A and Chicx-D (see Fig. 1a for location). The rectangles with a negative density contrast of $-0.1 \mathrm{~g} / \mathrm{cm}^{-3} \mathrm{represent}$ the inward dipping low-velocity-zone shown in Fig. 1b. The shape of the stratigraphic uplift in model 1 has been taken from a $2 \mathrm{D}$ slice through the $3 \mathrm{D}$ velocity tomogram of Morgan et al. (2002a) along the same profile as the gravity data. Model 2 shows a stratigraphic uplift with a diameter that decreases with depth, and model 3 shows a stratigraphic uplift with a diameter that increases with depth.

more deeply buried but denser uplift. Similar changes can be made to the width of the uplift, with appropriate adjustments to the density contrast. In fact, a wide range of density models will be consistent with both the gravity and velocity data because the conversion from velocity to density is only roughly linear to $\pm 10 \%$ (e.g., Ludwig et al. 1970; see also Fig. 6 ), the velocities are only known to $\sim 5 \%$ accuracy, and the velocities are smoothed over several hundred meters in a tomographic inversion.

The velocity data suggest that the stratigraphic uplift thins with increasing depth (Fig. 1b), but Hildebrand et al. (2003) argued that the stratigraphic uplift widened with increasing depth on the basis of the gravity data. For this reason, we investigated whether the gravity data can distinguish between a narrowing (as in model 2) or broadening (as in model 3) of the stratigraphic uplift with depth (Fig. 9). Models 2 and 3 both fit the data equally well. We conclude that, at this burial depth, the shape, depth, and density of the stratigraphic uplift are not well-constrained by gravity data. Our modeling in Fig. 9 shows that the gravity data cannot be used to distinguish between a stratigraphic uplift with a concave upward or flat top or between an uplift the diameter of which increases upward or downward. This is particularly true as there are no samples from below $1.63 \mathrm{~km}$, and the densities of individual rock types have to be estimated.

In conclusion, the velocity data presented in Morgan et al. $(2000 ; 2002 a)$ are consistent with the gravity data. The velocity anomalies are real, but their lithological interpretation and the exact placement of boundaries (Fig. 1b) remain ambiguous until confirmed by future calibration and drilling. All geophysical-based models of the central crater region, along with assertions that these models can be used to constrain the amount of melt produced by the impact, are overly optimistic. The precise lithology and structure of the central crater remains unclear and unproven.

\section{FUTURE OF THE PROJECT}

We propose to collate the physical property and geochemical data from Yax-1 and UNAM core samples so that we can assign a suite of physical properties to particular lithologies across the crater. We will use these data to 
calibrate our combined velocity, density, and magnetic models of the crater.

As part of this calibration, we need to be able to convert velocities measured on core samples in the laboratory to velocities measured using refraction experiments. It is generally accepted that $\mathrm{P}$ and $\mathrm{S}$ wave velocities $\left(\mathrm{V}_{\mathrm{P}}\right.$ and $\left.\mathrm{V}_{\mathrm{S}}\right)$ in fluid-saturated rocks, in contrast to dry rocks, vary with frequency. In practice, this means that ultrasonic velocities measured in the laboratory are higher than sonic log and refraction seismic velocities measured on the same lithology (e.g., Sams et al. 1997). With this in mind, we intend to make a new suite of measurements on the cores and use Gassmann's equations (Gassmann 1951) to estimate low-frequency fluidsaturated velocities from ultrasonic laboratory measurements on dry rocks, as described in King and Marsden (2002). The velocity values obtained from these calculations are more comparable to the low-frequency refraction velocities obtained from our tomographic inversions (Morgan et al. 2000, 2002a). With these, we will be able to place constraints on the range of lithologies that can explain the observed velocity anomalies (Fig. 1b).

A new 3D seismic experiment is planned for the summer of 2004 and will include a detailed investigation of the central crater. The aim of this experiment is to place much better constraints on the $3 \mathrm{D}$ velocity structure across the central crater and to improve constraints on the location of the velocity boundaries illustrated in Fig. 1b. We intend to acquire $\mathrm{S}$ wave velocity data, which might be a better indicator of some crater lithologies and, for example, help us differentiate between allogenic impact breccias and melt rocks. This seismic experiment will act in part as a site survey for two proposed offshore wells, IODP-1 and -2 (Fig. 1), to be drilled under the Integrated Ocean Drilling Program. IODP-1 will provide core through the entire sedimentary target sequence and will be used to better document the chemistry of the rocks involved in this impact. IODP-2 will be a $3 \mathrm{~km}$-deep hole that will penetrate the peak ring and will establish the lithological and structural character of the peak ring at Chicxulub.

The objective of our future research is to produce a more accurate model of Chicxulub and, in particular, to constrain the geometry of the stratigraphic uplift, the nature of the topographic peak ring, and the spatial distribution of the allogenic impact breccias and melt rocks. Such a model is crucial to understanding large craters in general and to guiding numerical modeling of large crater formation. When we can better tune our numerical models to successfully model a range of terrestrial craters, we can better constrain the impact energy and the environmental effects of impacts.

\section{ACKNOWLEDGMENTS}

We thank the International Continental Drilling Program for funding the drilling of Yaxcopoil-1 and Jaime UrrutiaFucugauchi and Ana Maria Soler-Arechalde for overseeing the core sampling at Universidad Nacional Autónoma de México. We thank Professor Michael King for his help and guidance throughout the laboratory measurements and interpretation. The acquisition of the 1996 seismic data was funded by NERC and NSF.

\section{Editorial Handling-Dr. Alex Deutsch}

\section{REFERENCES}

Alexopoulos J. S. and McKinnon W. B. 1994. Large impact craters and basins on Venus, with implications for ring mechanics on the terrestrial planets. In Large meteorite impacts and planetary evolution, edited by Dressler B. O., Grieve R. A. F., and Sharpton V. L. Special Paper 293. Boulder: Geological Society of America. pp. 29-50.

Anderson R. R., Hartung J. B., Witzke B. J., Shoemaker E. M., and Roddy D. J. 1994. Preliminary results of the U. S. Geological Survey, Iowa Department of Natural Resources Geological Survey Bureau, Manson Core Drilling Project. In Large meteorite impacts and planetary evolution, edited by Dressler B. O., Grieve R. A. F., and Sharpton V. L. Special Paper 293. Boulder: Geological Society of America. pp. 237-247.

Bell C., Morgan J. V., Hampson G. J., and Trudgill B. Stratigraphic and sedimentological observations from seismic data across the Chicxulub impact basin. Meteoritics \& Planetary Science. This issue.

Camargo-Zanoguera A. and Suárez-Reynoso G. 1994. Evidencia sísmica del cráter impacto de Chicxulub. Boletín de la Asociación Mexicana de Geofísicos de Exploración 34:1-28.

Campos-Enriquez J. O., Morales-Rodriquez H. F., DominquezMendez F., and Birch F. S. 1998. Gauss's theorem, mass deficiency at Chicxulub crater (Yucatán, Mexico), and the extinction of the dinosaurs. Geophysics 63:1585-1594.

Castagna J. P., Batzle M. L., and Kan T. K. 1993. Rock physics: The link between rock properties and AVO response. In Offsetdependent reflectivity-Theory and practice of AVO analysis, edited by Castagna J. P. and Backus M. M. Tulsa: Society of Exploration Geophysicists. pp. 135-171.

Christeson G. L., Buffler R. T., and Nakamura Y. 1999. Upper crustal structure of the Chicxulub impact crater from wide-angle ocean bottom seismograph data. In Large meteorite impacts and planetary evolution II, edited by Dressler B. O. and Sharpton V. L. Special Paper 339. Boulder: Geological Society of America. pp. 291-305.

Christeson G., Nakamura Y., Buffler R., Morgan J., and Warner M. 2001. Deep crustal structure of the Chicxulub impact crater. Journal of Geophyical Research 106:21751-21769.

Collins G., Melosh H. J., Morgan J. V., and Warner M. R. 2002. Hydrocode simulations of crater collapse and peak-ring formation. Icarus 157:24-33.

Dressler B. O., Sharpton V. L., Morgan J. V., Buffler R., Moran D., Smit J., Stöffler D., and Urrutia J. 2003. Investigating a 65-Maold smoking gun: Deep drilling of the Chicxulub impact structure. Eos Transactions 84:125, 130.

Deutsch A., Masaitis V. L., Ivanov B. A., and Pevzner L. 2004. Deep drilling in the Puchezh-Katunki impact structure, Russia. Lecture notes in Earth science. New York: Springer-Verlag. 392 p.

Ebbing J., Janle P., Koulouris J., and Milkereit B. 2001. 3D gravity modeling of the Chicxulub impact structure. Planetary and Space Science 49:599-609.

Espindola J. M., Mena M., Fuente J. O., and Campos-Enriquez J. O. 1995. A model of the Chicxulub impact structure (Yucatán, 
Mexico) based on gravity and magnetic signatures. Physics of the Earth and Planetary Interiors 92:271-278.

Gardner G. H. F., Gardner L. W., and Gregory A. R. 1974. Formation velocity and density: The diagnostic basics for stratigraphic traps. Geophysics 39:770-780.

Gassmann F. 1951. Über die Elastizität Poröser Medien. Vierteljahrsschrift der Naturforschenden Gesellschaft in Zürich 96:1-23.

Grieve R. A. F., Robertson P. B., and Dence M. R. 1981. Constraints on the formation of ring impact structures, based on terrestrial data. In Multi-ring basins, edited by Schultz P. H. and Merrill R. B. New York: Pergamon Press. pp. 37-57.

Grieve R. A. F. and Pesonen L. J. 1992. The terrestrial impact cratering record. Tectonophysics 216:1-30.

Grieve R. A. F. 1998. Extraterrestrial impacts on Earth: The evidence and the consequences. In Meteorites: Flux with time and impact effects, edited by Grady M. M., Hutchinson R., McCall G. J. H. and Rothery D. A. Special Publication 140. London: The Geological Society. pp. 105-131.

Grieve R. A. F. and Cintala M. 1999. Impact processes and giant impacts. In Encyclopedia of the solar system, edited by Weissman P., McFadden L. A., and Johnson T. London: Elsevier Academic Press. pp. 845-875.

Grieve R. A. F. and Therriault A. 2000. Vredefort, Sudbury, Chicxulub: Three of a kind? Annual Review of Earth Planetary Sciences 28:305-338.

Grieve R. A. F. and Therriault A. 2004. Observations at impact structures: What constraints have they provided on cratering processes. Meteoritics \& Planetary Science 39:199-216.

Hildebrand A. R., Pilkington M., Ortiz-Aleman C., Chavez R. E., Urrutia-Fucugauchi J., Connors M., Graniel-Castro E., CamargoZanoguera A. 1998b. Mapping Chicxulub crater structure with gravity and seismic reflection data. In Meteorites: Flux with time and impact effects, edited by Grady M. M., Hutchinson R., McCall G. J. H., and Rothery D. A. Special Publication 140. London: The Geological Society. pp. 177-193.

Hildebrand A. R., Millar J. D., Pilkington M., and Lawton D. C. 2003. Three dimensional gravity field modeling of the Chicxulub impact crater (abstract \#14414). Geophysical Research Abstracts 5.

Ivanov B. A. 1994. Geomechanical models of impact cratering: Puchezh-Katunki structure. In Large meteorite impacts and planetary evolution, edited by Dressler B. O., Grieve R. A. F., and Sharpton V. L. Special Paper 293. Boulder: Geological Society of America. pp. 81-91.

Ivanov B. A. and Artemieva N. A. 2002. Numerical modeling of the formation of large impact craters. In Catastrophic events and mass extinctions: Impact and beyond, edited by Koeberl C. and MacLeod K. Special Paper 356. Boulder: Geological Society of America. pp. 619-630.

Kenkmann T., Ivanov B. A., and Stöffler D. 2000. Identification of ancient impact structures: Low-angle normal faults and related geological features of crater basements. In Impacts and the early Earth, edited by Gilmour I. and Koeberl C. Lecture Notes in Earth Sciences 91. New York: Springer-Verlag. pp. 271-309.

Kenkmann T., Wittmann A., and Scherler D. 2004. Structure and impact indicators of the Cretaceous sequence of the ICDP drill core Yaxcopoil-1, Chicxulub impact crater, Mexico. Meteoritics \& Planetary Science. This issue.

King M. S. and Shams-Khanshir M. 1998. Petrophysics studies of sedimentary rocks from a cross-hole seismic test site. International Journal of Rock Mechanics and Mining Sciences 35:279-289.

King M. S. and Marsden J. R. 2002. Velocity dispersion between ultrasonic and seismic frequencies in brine-saturated reservoir sandstones. Geophysics 67:254-258.
Ludwig W. J., Nafe J. E., and Drake C. L. 1979. Seismic refraction. In The Sea, vol. 4, part 1, edited by Maxwell A. E. New York: Wiley-Interscience. pp. 53-84.

Melosh H. J. 1989. Impact cratering: A geologic process. New York: Oxford University Press. 245 p.

Melosh H. J. and Ivanov B. 1999. Impact crater collapse. Annual Review of Earth and Planetary Sciences 27:385-415.

Morgan J. V., Warner M., The Chicxulub Working Group, Brittan J., Buffler R., Camargo A., Christeson G., Denton P., Hildebrand A., Hobbs R., Macintyre H., Mackenzie G., Maguire P., Marin L., Nakamura Y., Pilkington M., Sharpton V., Snyder D., Suarez G., and Trejo A. 1997. Size and morphology of the Chicxulub impact crater. Nature 390:472-476.

Morgan J. V. and Warner M. R. 1999. The third dimension of a multiring impact basin. Geology 27:407-410.

Morgan J. V., Warner M. R., Collins G. S., Melosh H. J., and Christeson G. L. 2000. Peak ring formation in large impact craters. Earth and Planetary Science Letters 183:347-354.

Morgan J. V., Christeson G., and Zelt C. 2002a. Testing the resolution of a $3 \mathrm{D}$ velocity tomogram across the Chicxulub crater. Tectonophysics 355:215-226.

Morgan J. V., Warner M. R., and Grieve R. A. F. 2002b. Geophysical constraints on the size and structure of the Chicxulub impact crater. In Catastrophic events and mass extinctions: Impact and beyond, edited by Koeberl C. and MacLeod K. Special Paper 356. Boulder: Geological Society of America. pp. 39-46.

O'Keefe J. D. and Ahrens T. 1999. Complex craters: Relationship of stratigraphy and rings to impact conditions. Journal of Geophysical Research 104:27091-27104.

Ostermann M. 1996. Die Geochemie der Impaktschmelzdecke (Sudbury igneous complex) im Multiring-Becken Sudbury. Ph.D. thesis, University of Munster, Munster, Germany.

Picket G. R. 1963. Acoustic character logs and their applications in formation evaluation. Journal of Petroleum Technology 15:659667.

Pierazzo E. and Melosh H. J. 1999. Hydrocode modeling of Chicxulub as an oblique impact event. Earth and Planetary Science Letters 165:163-176.

Pike R. J. 1983. Comment on a "A schematic model of crater modification by gravity" by H. J. Melosh. Journal of Geophysical Research 88:2500-2504.

Pilkington M., Hildebrand A., and Ortiz-Aleman C. 1994. Gravity and magnetic field modeling and structure of the Chicxulub crater, Mexico. Journal of Geophysical Research 99:1314713162.

Poag C. W., Koeberl C., and Reimold U. 2004. The Cheaspeake Bay crater-Geology and geophysics of a late Eocene submarine impact structure. Heidelberg: Springer-Verlag. 522 p.

Pope K. O., Keiffer S. W., and Ames D. E. 2004. Empirical and theoretical comparisons of the Chicxulub and Sudbury impact structures. Meteoritics \& Planetary Science 39:97-116.

Pösges G. and Schieber M. 1994. Das Rieskrater-Museum Nördlingen, Akademiebericht Nr. 253 Bayerische Akademie für Lehrerfortbildung Dillingen. München: Dr. Friedrich Pfeil.

Sams M. S., Neep J. P., Worthington M. H., and King M. S. 1997. The measurement of velocity dispersion and frequency-dependent intrinsic attenuation in sedimentary rocks. Geophysics 62:14561464.

Smit J., van der Gaast S., and Lustenhouwer W. 2004. Is the transition impact to post-impact rock complete? Some remarks based on XRF scanning, electron microbe, and thin section analyses of the Yaxcopoil-1 core in the Chicxulub crater. Meteoritics \& Planetary Science. This issue.

Sharpton V. L., Marin L. E., Carney J. L., Lee S., Ryder G., Schuraytz 
B. C., Sikora P., and Spudis P. D. 1996. Model of the Chicxulub impact basin. In The Cretaceous-Tertiary event and other catastrophes in Earth history, edited by Ryder G., Fastovsky D., and Gartner S. Special Paper 307. Boulder: Geological Society of America. pp. 55-74.

Tao G., King M. S., and Nabi-Bidhendi 1995. Ultrasonic wave propagation in dry and brine-saturated sandstones as a function of effective stress: Laboratory measurements and modeling. Geophysical Prospecting 43:299-327.

Tsikalas F., Gudlaugsson S. T., and Faleide J. I. 1998. The anatomy of the buried complex impact structure: The Mjølnir structure, Barents Sea. Journal of Geophysical Research 107:30469-30483.

Urrutia-Fucugauchi J., Marin L., and Trejo-Garcia A. 1996. UNAM scientific drilling program of the Chicxulub impact structureEvidence for a $300 \mathrm{~km}$ crater diameter. Geophysical Research Letters 23:1565-1568.

Visnevsky S. and Montanari A. 1999. Popigai impact structure
(Arctic Siberia, Russia): Geology, petrology, geochemistry, and geochronology of glass-bearing impactites. In Large meteorite impacts and planetary evolution II, edited by Dressler B. O. and Sharpton V. L. Special Paper 339. Boulder: Geological Society of America. pp. 19-60.

Wünnemann K., Morgan J. V., and Jödicke H. Forthcoming. Is Ries a typical example of a middle-sized terrestrial crater? In Large meteorite impacts, edited by Kenkmann T. Boulder: Geological Society of America.

Zelt C. A. 1998. Lateral velocity resolution from three-dimensional seismic refraction data. Geophysical Journal International 135: 1101-1112.

Zelt C. A. and Barton P. J. 1998. Three-dimensional seismic refraction tomography: A comparison of two methods applied to data from the Faeroe Basin. Journal of Geophysical Research 103:7187-7210. 